\title{
Peningkatan Kinerja Keuangan Institusi Wakaf di Indonesia: Landasan Hukum, Pengawasan Hukum, Pengelolaan Nadzir, Manajemen Resiko, Kepatuhan Syariah
}

\author{
Muhammad Iskandar ${ }^{1}$ Dismane $^{2}$ Nugraha $^{3}$ Mayasari $^{4}$ \\ Doctroral, Management, Universitas Pendidikan Indonesia ${ }^{1,3}$ \\ Management, Universitas Pendidikan Indonesia ${ }^{2,4}$ \\ iskandardt@upi.edu \\ disman@upi.edu \\ nugraha@upi.edu \\ mayasari@upi.edu
}

\begin{abstract}
Abstrak
Artikel ini menganalisis efektivitas dan efisiensi kinerja keuangan lembaga wakaf di Indonesia terkait dengan landasan hukum, pengawasan, tata kelola nadzir, manajemen resiko dan kepatuhan syari'ah. Penelitian ini dilakukan di lembaga wakaf dengan populasi dan sampel diperoleh dari 102 lembaga wakaf, yang masing-masing lembaga memiliki 3 (tiga) nazir yang mengisi kuesioner penelitian ini. Data dianalisis dengan analisis deskriptif dan verifikatif serta pemodelan persamaan struktural partial least square. Secara umum, hasil penelitian menunjukkan bahwa efektivitas dan efisiensi kinerja keuangan lembaga wakaf di Indonesia dipengaruhi oleh landasan hukum, pengawasan, tata kelola nadzir, manajemen resiko dan kepatuhan syari'ah .
\end{abstract}

Kata kunci: lembaga wakaf, kinerja keuangan.

\begin{abstract}
This article analyzes the effectiveness and efficiency of the financial performance of waqf institutions in Indonesia in relation to legal foundations, supervision, nadzir governance, risk management and shari'ah compliance. This research was conducted in waqf institutions with a population and samples were obtained from 102 waqf institutions, each of which had 3 (three) nazirs who filled out the questionnaire for this study. The data were analyzed using descriptive and verification analysis as well as partial least square structural equation modeling. In general, the results of this study indicate that the effectiveness and efficiency of the financial performance of waqf institutions in Indonesia is influenced by legal foundations, supervision, nadzir governance, risk management and shari'ah compliance.
\end{abstract}

Keywords: waqf institution, financial performance.

\section{PENDAHULUAN}

Wakaf adalah salah satu instrumen Keuangan Sosial Islam (ISF), selain zakat, infaq, sedekah, dan hibah, yang dominan menjadi salah satu pilar ekonomi sejak masa lalu. Dalam implementasinya aset wakaf dikelola terlebih dahulu kemudian manfaat bersih yang muncul diberikan kepada mauquf 'alaih (penerima manfaat). Pasca kepemilikan aset wakaf dimiliki oleh Allah dan dikelola untuk kepentingan umat.

Baru-baru ini, diskusi tentang wakaf telah mulai menjadi perhatian utama oleh banyak pihak. Wakaf, termasuk Wakaf produktif, adalah komponen utama ISF yang tidak dapat dipisahkan dari Keuangan Komersial Islam dalam Sistem Keuangan Islam terpadu. Wakaf memiliki peran penting dalam
Dalam perkembangannya, wakaf memiliki peran dalam memberdayakan sektor sosial-ekonomi umat. Sebagai contoh, Imam Zufar pada abad ke-8 M telah menyarankan endowmen untuk diinvestasikan dalam bisnis dengan mekanisme bagi hasil (mudharaba) untuk menghasilkan keuntungan yang nantinya dapat digunakan untuk memberi manfaat kepada penerima manfaat wakaf (Çizakça, 2000). Namun, pada saat itu saran tersebut tidak memiliki aplikasi dalam perekonomian.

kehidupan sosial dan ekonomi masyarakat. Sifat wakaf yang melekat abadi akan menghasilkan akumulasi modal dengan periode yang sangat lama, yang akan meningkatkan kemampuan keuangan individu atau organisasi manajemen, sehingga berkontribusi positif untuk meningkatkan 
kesejahteraan rakyat. Hasil penggunaan wakaf tidak hanya terbatas pada pengurangan kemiskinan, tapi menciptakan pertumbuhan ekonomi, meningkatkan kesejahteraan sosial-ekonomi dan meningkatkan inklusi keuangan holistik. Selain itu, wakaf produktif melibatkan lebih banyak pihak, yang apabila dikelola oleh manajemen profesional, maka akan mampu menjaga stabilitas sistem keuangan..

Hingga saat ini, wakaf belum mampu memainkan peran yang efektif dalam memberdayakan sektor sosial-ekonomi masyarakat (Budiman, 2011). Penyebab belum maksimalnya wakaf di Indonesia sebagai instrumen pemberdayaan masyarakat, menurut Acarya \& Guruh (2009), dapat disebabkan oleh beberapa faktor, antara lain (1) tingkat literasi masyarakat tentang wakaf sangat rendah; (2) Kepercayaan publik pada lembaga manajemen wakaf rendah; (3) Wakaf belum menjadi kebiasaan masyarakat dan belum menjadi gaya hidup; (4) Tidak adanya database wakaf nasional, termasuk data tentang aset wakaf, wakif, dll.; (5) Tidak ada insentif untuk wakif; (6) Dualisme otoritas; (7) Dualisme Badan Wakaf Indonesia sebagai regulator dan operator; (8) Posisi Badan Wakaf Indonesia sebagai operator dan Lembaga Manajemen Wakaf swasta; (8) Nazhir belum menjadi pilihan karier; dan (9) Lemahnya profesionalisme Lembaga Manajemen Wakaf.

Marwah \& Bolz (2009) menekankan pentingnya mengubah pengelolaan wakaf menjadi struktur kelembagaan / perusahaan modern. Perubahan ini sejalan dengan karakteristik wakaf yang terkait dengan aspek daya tahan yang lebih lama. Karakteristik khusus wakaf itu sendiri dapat diperkuat dengan mekanisme tata kelola perusahaan yang baik (GCG). Foster \& Garduño (2013) dalam hal ini menekankan kesamaan antara prinsip-prinsip tata kelola dunia barat dan tata kelola syariah, terutama yang terkait dengan aspek keadilan, transparansi, dan akuntabilitas.

Bank Indonesia (BI) bersinergi dengan IRTI - IDB dan BWI bersinergi untuk menginisiasikan standar wakaf internasional yaitu Waqf Core Principles (WCP) . International Working Group on Waqf Core Principles beranggotakan: Lembaga Wakaf internasional: Kuwait, Afrika Selatan, Bosnia, Australia \& New Zealand

Berdasarkan kajian pada pendapat para ahli sebelumnya dan disesuaikan dengan penelitian saat ini pada lembaga wakaf di Indonesia, maka ditentukan indikator/pengukuran yang digunakan dalam Waqf Core Principles (pengelolaan wakaf), sebagai berikut.
Tabel 1. Indikator/Pengukuran Waqf Core Principles

\begin{tabular}{|c|c|c|}
\hline No & Indikator & Sumber \\
\hline 1 & Legal Foundation & \multirow{5}{*}{$\begin{array}{l}\text { The Cadbury Committee, 1992; Shleifer \& } \\
\text { Vishny, 1997; Tjager, et al., } \\
\text { 2003; Organization for Economic co- } \\
\text { Operation and Development/OECD, 2004; } \\
\text { Akhmad Syahroza, 2002; Ruin, } \\
\text { 2003; Siswanto \& Aldrige, 2005; Wahyudi } \\
\text { Zarkasyi, 2008; Waqf Core Principles } \\
\text { (2018) }\end{array}$} \\
\hline 2 & Waqf Supervision & \\
\hline 3 & Good Waqf Govemance & \\
\hline 4 & Risk Management & \\
\hline 5 & Sharia Govemance & \\
\hline
\end{tabular}

Berdasarkan kerangka kerja sistem manajemen wakaf, penelitian ini berfokus pada peningkatan kinerja keuangan lembaga wakaf. Kinerja keuangan lembaga wakaf dapat dikatakan baik atau tinggi jika kegiatan pengelolaan yang dilakukan oleh lembaga wakaf juga berjalan dengan baik dan lancar. Sementara itu, kegiatan manajemen wakaf tentu membutuhkan tata kelola yang baik dalam hal ini aspek landasan hukum, pengawasan wakaf, tata kelola nadzir yang baik, manajemen resiko dan aspek kepatuhan syari'ah. Lima aspek tersebut dikenal dengan waqf core principle (WCP).

\section{METODE PENELITIAN}

Jenis penelitian yang digunakan bersifat deskriptif dan verifikatif dengan metode survey explanatory. Adapun teknik analisis data yang digunakan dalam penelitian ini, yaitu uji validitas, uji realibilitas, analisis deskriptif dan analisis verifikatif. Penelitian ini dilakukan di lembaga wakaf dengan populasi dan sampel diperoleh dari 102 lembaga wakaf, yang masing-masing lembaga memiliki 3 (tiga) nazir yang mengisi kuesioner penelitian ini.

Ada 5 faktor yang mempengaruhi peningkatan kinerja lembaga keuangan wakaf yaitu legal foundation (Landasan Hukum), Waqf Supervision (Pengawasan Wakaf), Good Waqf Governance (Tata kelola Nadzir), Risk Management (Manajemen Resiko), Sharia Governance (Kepatuhan Syaria'ah)

\section{Hasil Penelitian dan Pembahasan}

Pada hasil penelitian diuraikan mengenai (1) analisis deskriptif setiap variabel yang diteliti, (2) analisis verifikatif menggunakan PLS (yang mencakup model pengukuran dan model struktural untuk menguji hipotesis).

\section{Analisis Deskriptif Waqf Core Principles}

Waqf Core Principle (WCP) dalam penelitian ini adalah konstruk dari variabel laten endogen yang diwakili oleh 5 (lima) dimensi atau variabel manifes dimensi, yaitu: Legal Foundation (WCP1), Waqf 
Supervision (WCP2), Good Waqf Governance (WCP3), Risk Management (WCP4), dan Sharia Governance (WCP5). Setiap dimensi memiliki ukuran masing-masing sehingga semuanya ada 20 item pernyataan dalam variabel ini. disajikan tanggapan nazir pada lembaga wakaf di Indonesia untuk variabel Waqf Core Principles dan semua dimensinya berdasarkan skor rerata, standar deviasi, dan kategorinya

Tabel 2. Tanggapan Nazir terkait Waqf Core Principles

\begin{tabular}{|c|c|c|c|}
\hline Indikator & Rerata & $\begin{array}{l}\text { Std. } \\
\text { Dev. }\end{array}$ & Kategori \\
\hline Legal foundation & 3.65 & 0.87 & $\begin{array}{l}\text { Cukup } \\
\text { Tinggi }\end{array}$ \\
\hline Wagf supervision & 3.57 & 0.93 & $\begin{array}{l}\text { Cukup } \\
\text { Tinggi }\end{array}$ \\
\hline $\begin{array}{l}\text { Good waqf } \\
\text { govemance }\end{array}$ & 3.63 & 0.94 & $\begin{array}{l}\text { Cukup } \\
\text { Tinggi }\end{array}$ \\
\hline Risk management & 3.59 & 0.88 & $\begin{array}{l}\text { Cukup } \\
\text { Tinggi }\end{array}$ \\
\hline Sharia govemance & 3.49 & 0.94 & $\begin{array}{l}\text { Cukup } \\
\text { Tinggi }\end{array}$ \\
\hline $\begin{array}{l}\text { Waqf Core Principles } \\
\text { (WCP) }\end{array}$ & 3.59 & 0.91 & $\begin{array}{l}\text { Cukup } \\
\text { Tinggi }\end{array}$ \\
\hline
\end{tabular}

Tabel diatas tersebut memperlihatkan bahwa capaian skor rata-rata untuk variabel laten Waqf Core Principles itu termasuk cukup tinggi (dengan rerata sebesar 3,59 dari ideal 5,0). Tabel tersebut juga memperlihatkan bahwa capaian dari dimensi dalam variabel Waqf Core Principles ini semuanya cukup tinggi. Secara visual capaian rata-rata skor penilaian responden mengenai implementasi Waqf Core Principles (WCP) dapat disajikan pada Gambar di bawah ini:

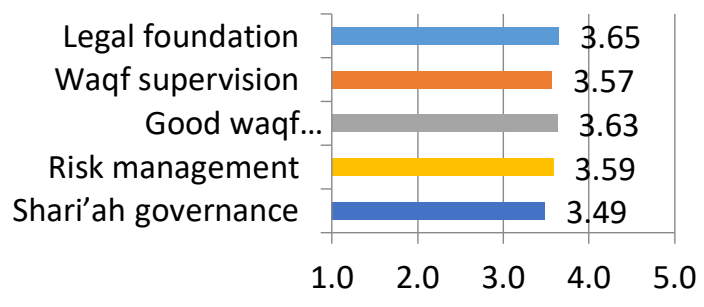

\section{Gambar 1. Deskripsi Waqf Core Principles}

Data-data pada tabel dan gambar tersebut memperlihatkan bahwa:

1. Capaian dimensi Legal Foundation (WCP1) pada konstruk Waqf Core Principles termasuk pada kategori cukup tinggi dengan skor rerata sebesar 3,65 yang merupakan skor paling tinggi dibandingkan dengan dimensi-dimensi lainnya dalam konstruk ini. Kondisi ini menunjukkan bahwa nazir pada lembaga wakaf di Indonesia sudah cukup memahami landasan hukum Waqf Core Principles, yang terdiri atas Responsibilities, Objectives, Powers, Independence, Accountability, dan Collaboration. Para nazir tersebut juga sudah mengimplementasikan prinsip-prinsip tersebut dalam mengelola wakaf. Walau begitu, pemahaman nazir atas legal foundation ini, juga implementasinya, memiliki variabilitas yang sangat beragam di antara lembaga-lembaga wakaf di Indonesia.

2. Capaian dimensi Waqf Supervision (WCP2) pada konstruk Waqf Core Principles ini juga termasuk pada kategori cukup tinggi dengan skor rerata sebesar 3,57. Dalam hal ini, nazir pada lembaga wakaf di Indonesia mempersepsi bahwa pendekatan mengenai supervisi wakaf ini sudah didasarkan pada skema supervisi secara terpadu yang mencakup semua aspek terkait penghimpunan, investasi, pengelolaan, dan penyaluran wakaf.

3. Capaian dimensi Good Waqf Governance (WCP3) pada konstruk Waqf Core Principles ini juga termasuk pada kategori cukup tinggi dengan skor rerata sebesar 3,63. Pada dasarnya, nazir pada lembaga wakaf di Indonesia sudah maslahat sebagai bentuk tanggung jawab memberikan manfaat optimal bagi mauquf'alaih. Sebagai bentuk tanggung jawab kepada wakif, para nazir juga sudah cukup transparan dalam hal pelaporan keuangan dan kinerja keuangan lembaga wakaf. Dilihat dari produktivitas, para nazir sudah menunjukkan kemampuan mengelola dana secara produktif. Nazir juga sudah amanah (trustable) dan memiliki integritas untuk menghindar dari menyelewengkan amanah atau melanggar hukumhukum Islam. Terakhir, para nazir pada umumnya sudah mampu mempertahankan keberlangsungan (sustainability) nilai dari asetaset wakaf yang dikelolanya.

4. Capaian dimensi Risk Management (WCP4) pada konstruk Waqf Core Principles ini juga termasuk pada kategori cukup tinggi dengan skor rerata sebesar 3,59. Dalam hal ini, para nazir di lembaga wakaf di Indonesia sudah cukup memiliki proses manajemen risiko yang komprehensif untuk mengidentifikasi, mengukur, mengevaluasi, memantau, melaporkan, dan mengendalikan atau mengurangi semua risiko material secara tepat waktu dan untuk menilai kecukupan modal dan likuiditas mereka dalam kaitannya dengan profil 
risiko dan kondisi pasar serta kondisi ekonomi makro. Ini meluas ke pengembangan dan peninjauan rencana pemulihan yang kuat dan kredibel yang mempertimbangkan keadaan khusus lembaga wakaf. Proses manajemen risiko sepadan dengan profil risiko dan kepentingan sistemik lembaga wakaf.

5. Capaian dimensi Sharia Governance (WCP6) pada konstruk Waqf Core Principles ini juga termasuk pada kategori cukup tinggi dengan skor rerata sebesar 3,49, walaupun jika dibandingkan dengan dimensi-dimensi lainnya, dimensi ini merupakan yang paling rendah. Pada dasarnya nazir memahami bahwa lembaga wakaf yang dikelolanya sudah memiliki proses manajemen risiko kepatuhan operasional dan syariah yang tepat untuk meminimalkan potensi praktik penipuan, mengantisipasi gangguan sistem, dan gangguan potensial lainnya. Sharia governance ini pada dasarnya mencakup Operational and Sharia-Compliance Risk, Sharia Compliance and Internal Audit, dan Financial Reporting and External Audit.

\section{Analisis Deskripsi Kinerja Keuangan Lembaga Wakaf}

Kinerja keuangan (KK) dalam penelitian ini adalah konstruk dari variabel laten endogen yang diwakili oleh 2 (dua) dimensi atau variabel manifes dimensi, yaitu: Efektivitas (KK1) dan Efisiensi (KK2). Setiap dimensi diukur oleh empat indikator sehingga semuanya ada 8 item pernyataan dalam variabel kinerja keuangan ini. Pada Tabel dibawah. disajikan tanggapan nazir pada lembaga wakaf di Indonesia untuk variabel kinerja keuangan dan semua dimensinya berdasarkan skor rerata, stander deviasi, dan kategorinya

Tabel 3. Tanggapan Nazir terkait Kinerja Keuangan

\begin{tabular}{lrrl}
\hline \multicolumn{1}{c}{ Indikator } & Rerata & $\begin{array}{r}\text { Std. } \\
\text { Dev. }\end{array}$ & Kategori \\
\hline Efektivitas & 3.56 & 0.88 & $\begin{array}{l}\text { Cukup } \\
\text { Tinggi } \\
\text { Cukup }\end{array}$ \\
Efisiensi & 3.55 & 0.85 & Tinggi \\
\hline $\begin{array}{l}\text { Kinerja Keuangan } \\
\text { (KK) }\end{array}$ & 3.56 & 0.87 & $\begin{array}{l}\text { Cukup } \\
\text { Tinggi }\end{array}$ \\
\hline
\end{tabular}

Tabel 3. di atas memperlihatkan bahwa capaian skor rerata untuk variabel laten kinerja keuangan itu cukup tinggi yaitu sebesar 3,56 (dari ideal 5,00). Tabel tersebut juga memperlihatkan bahwa capaian dari kedua dimensi dalam variabel kinerja keuangan ini juga semuanya cukup tinggi. Secara visual capaian rata-rata skor penilaian responden mengenai Kinerja Keuangan (KK) lembaga wakaf dapat disajikan pada Gambar dibawah ini:

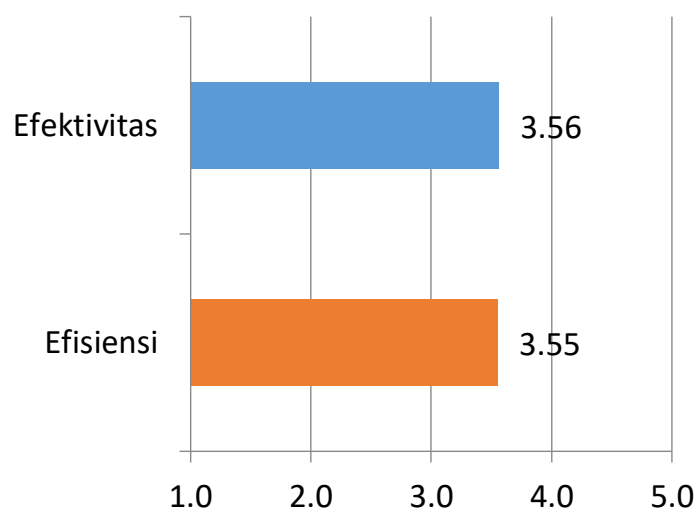

\section{Gambar 2. Deskripsi Kinerja Keuangan}

Data-data pada tabel 3. dan gambar 2. tersebut memperlihatkan bahwa:

1. Capaian dimensi Efektivitas (KK1) pada konstruk Kinerja Keuangan termasuk pada kategori cukup tinggi dengan rerata sebesar 3,56. Dimensi ini pada dasarnya terkait dengan administrative effectiveness, program effectiveness, fundraising effectiveness, dan other financial performance measures effectiveness. Pada dasarnya, para nazir pada lembaga wakaf di Indonesia mempersepsi bahwa kinerja administrasi, kinerja program, penghimpunan dana, dan kinerja keuangan lainnya sudah cukup efektif.

2. Capaian dimensi Efisiensi (KK2) pada konstruk Kinerja Keuangan juga termasuk pada kategori cukup tinggi dengan rerata sebesar 3,55. Dimensi ini pada dasarnya terkait dengan administrative efficiency, program efficiency, fundraising efficiency, dan other financial performance measures efficiency. Pada dasarnya, para nazir pada lembaga wakaf di Indonesia mempersepsi bahwa kinerja administrasi, kinerja program, penghimpunan dana, dan kinerja keuangan lainnya sudah cukup efisien.

\section{Analisis Verifikatif (PLS)}

Perhitungan analisis verifikatif dalam penelitian ini dianalisis menggunakan Partial Least Square Path Modeling (PLS-PM). Perhitungannya dibantu oleh program ADANCO versi 2.1.1. Berdasarkan hasil perhitungan PLS-PM, model peningkatan kinerja keuangan melalui implementasi Waqf Core Principles pada lembaga wakaf di Indonesia, dapat disajikan pada Gambar berikut: 


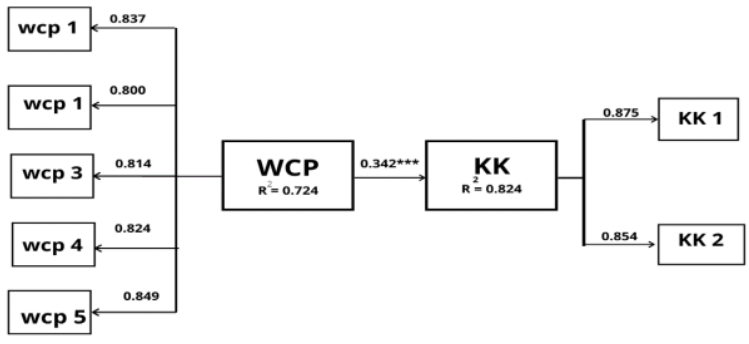

Gambar 3. Implementasi Waqf Core Principles

\section{Model Pengukuran}

\section{Construct Reliability}

Perhitungan construct reliability menggunakan Dijkstra-Henseler's rho $\left(\rho_{\mathrm{A}}\right)$, composite reliability $\left(\rho_{C}\right)$, dan Cronbach's alpha $(\alpha)$ dapat disajikan pada Tabel berikut:

Tabel 4. Construct Reliability

\begin{tabular}{lccc}
\hline Construct & $\begin{array}{c}\text { Dijkstra- } \\
\text { Henseler's } \\
\text { rho }\left(\boldsymbol{\rho}_{\mathrm{A}}\right)\end{array}$ & $\begin{array}{c}\text { Jöreskog's } \\
\text { rho }\left(\boldsymbol{\rho}_{\mathbf{c}}\right)\end{array}$ & $\begin{array}{c}\text { Cronbach's } \\
\text { alpha( } \boldsymbol{\alpha})\end{array}$ \\
\hline WCP & 0.884 & 0.914 & 0.883 \\
\hline KK & 0.715 & 0.855 & 0.712 \\
\hline
\end{tabular}

Sumber: Hasil Pengolahan Data PLS menggunakan ADANCO (2020)

Pengukuran construct reliability merupakan estimasi reliabilitas terkait dengan model pengukuran reflektif. Hasil perhitungan dianggap reliabel jika nilainya > 0.7. Tabel menunjukkan bahwa semua konstruk memiliki nilai > 0.7 sehingga konstruk implementasi Waqf Core Principles dan kinerja keuangan lembaga wakaf dinyatakan reliabel dan mendukung ke arah model yang baik.

\section{Convergent Reliability}

Perhitungan convergent reliability menggunakan pengukuran Average Variance Extracted (AVE) yang biasanya diinterpretasikan sebagai ukuran unidimensionality. Konstruk reflektif menunjukkan unidimensionality yang baik jika nilai AVE lebih dari 0.5 (Fornell \& Larcker, 1981). Hasil perhitungan convergent reliability menggunakan AVE dapat disajikan sebagai berikut.
Tabel 5. Convergent Reliability

\begin{tabular}{lc}
\hline Construct & Average variance extracted (AVE) \\
\hline WCP & 0.681 \\
\hline KK & 0.747 \\
\hline Sumber: L Hasil Pengolahan Data PLS (2020)
\end{tabular}

Hasil perhitungan menunjukkan bahwa nilai AVE untuk setiap konstruk itu lebih dari 0.5 sehingga dapat dinyatakan bahwa semua konstruk memiliki unidimensionality yang baik.

\section{Discriminant Validity}

Fornell-Larcker criterion menyatakan bahwa AVE dari suatu konstruk hendaknya lebih tinggi daripada nilai korelasi kuadrat (squared correlations) dengan konstruk lain dalam model tersebut. Adapun heterotrait-monotrait ratio of correlations (HTMT) mengukur validitas diskriminan dari semua faktor. Nilai HTMT hendaknya lebih rendah dari 0.9 atau 0.85. Hasil perhitungan discriminant validity menggunakan Fornell-Larcker criterion dan HTMT dapat disajikan sebagai berikut:

\section{Tabel 6. Discriminant Validity}

Discriminant Validity: Heterotrait-Monotrait Ratio of Correlations (HTMT)

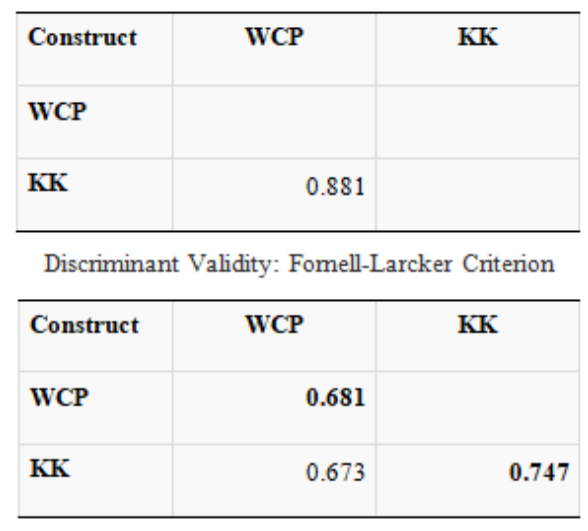

Squared correlations; AVE in the diagonal.

Hasil perhitungan menunjukkan bahwa hampir semua nilai HTMT berada di bawah 0.9 dan pada FornellLarcker Criterion dapat dilihat bahwa nilai AVE (yang diberi tanda tebal) lebih tinggi daripada nilai masingmasing korelasi kuadratnya. Discriminant validity ini menunjukkan bahwa setiap konstruk yang diteliti memang memiliki perbedaan karakteristik dalam 
konsepnya. Dengan kata lain suatu konstruk memiliki konsep yang berbeda dengan konstruk lainnya.

\section{Factor loadings dan cross loadings}

Factor loadings dan cross loadings merupakan slope dari regresi sederhana dari

suatu indikator dengan konstruknya. Adapun cross loadings matrix merupakan korelasi antara setiap indikator dengan masing-masing konstruk. Tabel dibawah ini:

Tabel 7. Factor Loadings

\begin{tabular}{lll}
\hline \hline Indicator & WCP & KK \\
\hline & & \\
WCP1 & 0.837 & \\
WCP2 & 0.800 & \\
WCP3 & 0.814 & \\
WCP4 & 0.824 & \\
WCP5 & 0.849 & \\
KK1 & & 0.875 \\
KK2 & & 0.854 \\
\hline
\end{tabular}

Sumber: Hasil Pengolahan Data PLS (2020)

Tabel 8. Cross Loadings Matrix

\begin{tabular}{lcc}
\hline \hline Indicator & WCP & KK \\
\hline WCP1 & 0.837 & 0.732 \\
WCP2 & 0.800 & 0.641 \\
WCP3 & 0.814 & 0.747 \\
WCP4 & 0.824 & 0.727 \\
WCP5 & 0.849 & 0.676 \\
KK1 & 0.766 & 0.875 \\
KK2 & 0.714 & 0.854 \\
\hline \hline
\end{tabular}

Sumber: Hasil Pengolahan Data PLS (2020)

Hasil perhitungan factor loadings dan cross loading matrix di atas memperlihatkan bahwa setiap indikator (dimensi atau variabel manifes) secara valid dan reliabel mampu merefleksikan masing-masing konstruknya, dan mampu menunjukkan perbedaan konseptual (maupun secara statistik) antara setiap indikator pada satu konstruk dengan indikator lain pada konstruk lainnya Pada dasarnya, semua indicator dan semua konstruk mengarah pada model yang baik sebagai dasar untuk pengujian hipotesis, seperti yang dianalisis dalam model struktural. Pengujian model struktural dibahas pada bagian berikut.

\section{Model Struktural}

Hasil perhitungan pengaruh langsung, tidak langsung, dan total, juga signifikansi setiap pengaruh (dilihat dari p-value), dan efek mediasi disajikan pada.
Tabel 9. Path coefficients, Indirect Effect, dan Total Effects

\begin{tabular}{lrrrrr}
\hline \hline Effect & Beta & $\begin{array}{r}\text { Indirect } \\
\text { effects }\end{array}$ & $\begin{array}{r}\text { p-value } \\
(2-\text { sided })\end{array}$ & $\begin{array}{c}\text { Total } \\
\text { effect }\end{array}$ & $\begin{array}{c}\text { Mediating } \\
\text { effect }\end{array}$ \\
\hline$W C P \rightarrow$ KK & 0.342 & 0.125 & 0.000 & 0.468 & partial
\end{tabular}

Sumber: Hasil Pengolahan Data PLS (2020)

Dilihat dari p-value dapat dinyatakan bahwa semua koefisien jalur (beta) terbukti signifikan sehingga semua hipotesis yang diajukan dapat diterima.

\section{Effect size (Cohen's f $\left.\mathbf{f}^{2}\right)$}

Effect size $\left(\mathrm{f}^{2}\right)$ menunjukkan seberapa penting atau seberapa substantial kontribusi suatu pengaruh langsung (dari eksogen ke endogen). Nilainya dapat lebih atau sama dengan nol. Interpretasi nilai $\mathrm{f}^{2}$ mengacu pada kriteria dari Cohen (1988),

Berdasarkan hasil perhitungan, nilai $\mathrm{f}^{2}$ untuk masingmasing jalur dapat disajikan pada tabel.

Tabel 10. Effect size (Cohen's $\mathbf{f}^{2}$ )

\begin{tabular}{lccccl}
\hline \hline Effect & Beta & $\begin{array}{c}\text { Indirect } \\
\text { effects }\end{array}$ & $\begin{array}{c}\text { Total } \\
\text { effect }\end{array}$ & $\begin{array}{c}\text { Cohen's } \\
\mathrm{f}^{2}\end{array}$ & Interpretation \\
\hline WCP $\rightarrow$ KK & 0.342 & 0.125 & 0.468 & 0.162 & Moderate
\end{tabular}

Sumber: Hasil Pengolahan Data PLS (2020)

Interpretasi dari nilai $\mathrm{f}^{2}$ menunjukkan bahwa WCP terhadap KK termasuk cukup kuat (moderate effect).

\section{HASIL DAN PEMBAHASAN}

\section{Pembahasan Analisis Deskriptif}

Mengacu pada hasil analisis deskriptif, ditemukan bahwa setiap konstruk pada penelitian ini terdapat beberapa keunggulan dan kelemahan pada setiap dimensinya. Berdasarkan hasil perhitungan, semua konstruk termasuk pada kategori cukup tinggi (ratarata di atas 3,00 dari ideal 5,00). Namun demikian, terdapat beberapa dimensi pada setiap konstruk tersebut yang lebih tinggi atau lebih rendah daripada dimensi-dimensi lainnya

\section{Pembahasan Deskripsi Waqf Core Principles}

Hasil analisis deskriptif pada bagian sebelumnya menunjukkan bahwa implementasi Waqf Core Principles yang dipersepsi nazir pada lembaga wakaf di Indonesia itu sudah cukup tinggi dan beragam, tetapi pada umumnya implementasi tersebut dinilai masih belum sepenuhnya optimal. 
Dimensi legal foundation pada umumnya dipersepsi cukup tinggi oleh nazir mengenai pentingnya memahami landasan hukum yang diperlukan dalam mengelola wakaf. Berkaitan dengan itu, Kuran, T. (2001) menjelaskan bahwa dengan adanya keunggulan dan keterbatasan sistem wakaf, maka diperlukan suatu pedoman yang berlandaskan hukum-hukum syariah Islam. Keberadaan Waqf Core Principles dinilai dapat menjadi pedoman bagi nazir untuk lebih terarah dalam mengelola wakaf, terutama pada abad ke-21 ini.

Dimensi waqf supervision juga dinilai penting dalam proses pengelolaan wakaf. Dimensi ini menekankan pengawasan sektor wakaf pada tingkat kehati-hatian yang sama dengan sektor keuangan lainnya. Standar operasional disiapkan untuk mempertimbangkan langkah-langkah penyesuaian risiko berdasarkan kelas aset yang dikelola dan optimalisasi manfaat bagi masyarakat. Proses pengawasan menekankan proses antisipatif untuk meminimalkan praktik penyelewengan dana, baik secara sentralisasi maupun desentralisasi. Aktivitas utama dalam pengelolaan wakaf, yaitu penghimpunan, investasi, manajerial, dan penyaluran wakaf memerlukan pengawasan dari pihak yang berwenang secara internal maupun eksternal. Berkaitan dengan itu, Mohsin, M. I. A. (2010) menegaskan bahwa pengawasan langsung dari pemerintah atau lembaga keagamaan kepada wali amanat sangat dihargai untuk menghindari mismanajemen dalam lembaga wakaf ini di satu pihak, dan untuk memastikan manfaat wakaf secara berkelanjutan bagi umat.

Dimensi good waqf governance di sini lebih berkaitan dengan good nazir governance untuk mengelola wakaf dalam suatu lembaga wakaf dengan menekankan pada aspek-aspek maslahah, transparency, productivity, trustable, dan sustainability. Kebangkitan lembaga wakaf menciptakan kebutuhan akan kerangka kerja tata kelola yang baik (good governance), yang dapat meningkatkan transparansi dan akuntabilitas lembaga tersebut (Ramli, N. M., \& Muhamed, N. A., 2013). Dengan adanya good nazir governance, diharapkan bahwa pengelolaan wakaf dapat mematuhi praktik tata kelola yang baik, melalui Dewan Penasihat Syariah, manajemen yang baik, pelaporan keuangan, dan auditing.

Dimensi risk management berkaitan dengan kenyataan bahwa nazir atau lembaga wakaf telah menerapkan proses manajemen risiko yang komprehensif untuk mengidentifikasi, mengukur, mengevaluasi, memantau, melaporkan, dan mengendalikan atau memitigasi semua risiko material secara tepat waktu dan untuk menilai kecukupan modal dan likuiditas mereka dalam kaitannya dengan profil risiko dan pasar serta kondisi ekonomi makro. Hal ini meluas ke pengembangan dan peninjauan rencana pemulihan yang kuat dan kredibel, dengan mempertimbangkan kondisi tertentu suatu lembaga wakaf. Proses manajemen risiko sepadan dengan profil risiko dan kepentingan sistemik lembaga wakaf. Menurut Alias, T. A. (2012), risk-management sebagai salah satu bagian penting dalam good waqf governance perlu mempertimbangkan cost-benefit dan risk-returns dalam mengelola wakaf secara keseluruhan.

Terakhir, dimensi sharia governance di sini mengacu pada tugas paling penting dari regulator untuk mengawasi manajemen wakaf, yang mencakup memastikan kepatuhan Syariah, transparansi keuangan, dan efisiensi ekonomi. Oleh karena itu, ada kebutuhan untuk membangun sistem pendukung yang kuat, seperti memperkuat fungsi Dewan Pengawas Syariah, standarisasi sistem akuntansi dan pelaporan wakaf, penilaian kinerja manajemen wakaf, sistem pemantauan untuk efisiensi operasional, ekonomi dan dampak sosial bagi penerima manfaat (mauquf alaih), dan kolaborasi dengan lembaga keuangan dan keuangan mikro syariah. Pada dasarnya, suatu lembaga wakaf harus memiliki proses manajemen risiko kepatuhan operasional dan syariah yang tepat untuk meminimalkan potensi praktik penipuan, mengantisipasi gangguan sistem, dan gangguan potensial lainnya. Temuan ini sejalan dengan hasil penelitian Hamza, H. (2013) bahwa sharia governance dapat diterapkan dalam lembaga keuangan Islam untuk meningkatkan efektivitas dan model pengawasan yang tepat.

\section{Pembahasan Deskripsi Kinerja Keuangan}

Hasil analisis deskriptif pada bagian sebelumnya menunjukkan bahwa kinerja keuangan lembaga wakaf yang dipersepsi nazir pada lembaga wakaf di Indonesia itu sudah cukup tinggi dan beragam, tetapi pada umumnya kinerja keuangan lembaga wakaf tersebut dinilai masih belum sepenuhnya optimal.

Efektivitas dan efisiensi kinerja keuangan ini tampak dalam aspek administrasi, program, fundraising, dan pengukuran kinerja keuangan lainnya. Efektivitas dan efisiensi kinerja keuangan lembaga wakaf di Indonesia tampaknya berjalan seiringan.

Penelitian ini menemukan bahwa kesehatan dan kinerja keuangan lembaga wakaf sangat penting untuk keberlanjutan keberadaan dan operasi lembaga tersebut. Dengan demikian, menentukan kekuatan keuangan dan kerentanan lembaga wakaf sangat penting dan kongruen dengan keberadaan wakaf yang berkelanjutan. Transparansi dan akuntabilitas menjadi patokan utama dalam menilai kinerja keuangan. Selain 
itu, kepercayaan dari masyarakat dapat menjadi isu utama terkait kinerja keuangan ini.

Penelitian sebelumnya dari Sulaiman, M., \& Zakari, M. A. (2015) mengungkap empat rasio penting kesehatan dan kinerja keuangan dihitung: rasio keseimbangan ekuitas, indeks konsentrasi pendapatan, rasio biaya administrasi dan rasio margin operasi. Temuan menunjukkan bahwa lembaga, rata-rata, cukup efisien dan efektif dalam mengelola dan mengelola properti wakaf. Meskipun ini merupakan upaya pertama yang sederhana, penelitian ini memberikan wawasan tentang efisiensi dan efektivitas nazir dalam melaksanakan tugasnya untuk meningkatkan efektivitas dan efisiensi kinerja keuangan lembaga wakaf.

\section{Pembahasan Analisis Keterkaitan Variabel}

Analisis keterkaitan variabel menunjukkan bahwa kinerja keuangan lembaga wakaf dapat dibangun oleh aspek-aspek kinerja non-keuangan, implementasi Waqf Core Principles dalam governance atau pengelolaan wakaf. Hubungan atau koefisien korelasi antara kelima variabel itu sangat erat dan saling terkait. Kondisi ini menunjukkan bahwa kinerja keuangan suatu lembaga wakaf akan baik jika faktorfaktor kinerja non-keuangan juga baik.

Analisis PLS menunjukkan bahwa efektivitas dan efisiensi kinerja keuangan tampak dari keberhasilan lembaga wakaf dalam meengelola manajerial melalui implementasi waqf core principles.

Pada dasarnya penelitian ini mengkonfirmasi temuantemuan sebelumnya dari Ahmed, H. (2004); Cajee, Z.A. and Barzinji, D.J. (2008); Kahf, M. (1999); Mannan, M.A. (1998); Masyita, D., Tasrif, M. and Telaga, A. S. (2005); Zarka, M.A. (2007); dan Zikmund, W.G. (2003), mengenai keterkaitan pengelolaan dana wakaf dan kinerja keuangan lembaga wakaf

\section{SIMPULAN DAN SARAN}

\section{Simpulan}

Berdasarkan hasil penelitian dan pembahasan, dapat ditarik kesimpulan terkait dengan model peningkatan kinerja keuangan lembaga wakaf di Indonesia bahwa Implementasi Waqf Core Principles berpengaruh positif terhadap kinerja keuangan secara langsung Hal ini berarti bahwa tingkat implementasi Waqf Core Principles juga dapat mempengaruhi tinggi rendahnya kinerja keuangan.

\section{Saran}

Dimensi waqf supervisor dan sharia governenace pada implementasi Waqf Core Principles belum sepenuhnya optimal sehingga perlu lebih ditingkatkan. Upaya-upaya peningkatan tersebut dapat dilakukan melalui koordinasi dengan badan pengawas syariah sehingga implementasi Waqf Core Principles secara keseluruhan dapat berjalan dengan lebih baik.

\section{DAFTAR PUSTAKA}

Abdullah, M. (2015). A new framework of corporate governance for Waqf: a preliminary proposal. Islam and Civilisational Renewal, 274(2625), 1-18.

Abraham, A. (2006). Financial Management in the Nonprofit Sectors: A Mission - Based Approach to Ratio Analysis in Membership Organizations. The Journal of American Academy of Business, 9(2), 212-217.

Acarya DY, Guruh SR. (2009). Analisis Efisiensi Perbankan Konvensional dan Perbankan Syariah di Indonesia dengan Data Envelopment Analysis: Current Issues Lembaga Keuangan Syariah, edited by Nurul Huda and Mustofa Edwin Nasution. Jakarta: Prenada Media Group..

Aisyah M. (2014) The role of zakah and binary economics in poverty reduction. Esensi: Jurnal Bisnis dan Manajemen. 2014 Aug 8;4(2).

Alias, T. A. (2012). Venture capital strategies in waqf fund investment and spending. ISRA International Journal of Islamic Finance, 195(1013), 1-54.

Armendáriz B, D'Espallier B, Hudon M, Szafarz A. (2013). Subsidy uncertainty and microfinance mission drift. Available at SSRN 1731265. 2013 Apr 20.

Atan, R., Zainon, S., Aliman, S. \& Nam, R.Y. (2013). Financial Management in Religious Non-Profit Organizations: A Mission Based Approach to Ratio Analysis. International Conference on Advanced Computer Science and Electronics Information (ICACSEI).

Azis Y, \& Osada H. (2010). An empirical study of new value creation in financial service companies using design for Six Sigma approach. International Journal of Productivity and Quality Management. 2010 Dec 27;7(1):104-24.

Budiman AA. (2011). Akuntabilitas lembaga pengelola wakaf. Walisongo: Jurnal Penelitian Sosial Keagamaan. 2011 Jun 7;19(1):75-102.

Çizakça M. A (2000). History of philanthropic foundations: The Islamic world from the seventh century to the present. Istanbul: Boğaziçi University Press; 2000. 
Dewi, M. K., \& Ferdian, I. R. (2012). Evaluating performance of Islamic mutual funds in Indonesia and Malaysia. Journal of Applied Economics and Business Research, 2(1), 11-33.

Epstein, M. J., Buhovac, A. R., \& Yuthas, K. (2015). Managing social, environmental and financial performance simultaneously. Long range planning, 48(1), 35-45.

Fadilah S. (2015). Going Concern: An Implementation in Waqf Institutions (Religious Charitable Endowment). Procedia-Social and Behavioral Sciences. 2015 Nov 25;211:356-63.

Faradis, J. (2015). The determinants of waqf preference toward money-cash waqf. Global Review of Islamic Economics and Business, 2(3), 219-229.

Fay, M. A. (1997). Women and waqf: Toward a reconsideration of women's place in the Mamluk household. International Journal of Middle East Studies, 29(1), 33-51.

Financial Reporting Council, (2012) UK Corporate Governance Code, available at: http://www.frc.org.uk/OurWork/Publications/CorporateGovernance/UKCorporate-Governance-CodeSeptember-2012.aspx

Foster S, Garduño H. (2013). Groundwater-resource governance: Are governments and stakeholders responding to the challenge?. Hydrogeology Journal. 2013 Mar 1;21(2):317-20.

Griffin K, McKinley T. (1994). A new framework for development cooperation,.Masyhadi, Ahamd. (2019). "Nilai-Nilai Tasawuf Ajaran Sunan Drajat." PhD diss., UIN Sunan Ampel Surabaya, 2019.

Hamada M. (2010). Commercialization of microfinance in Indonesia: The shortage of funds and the linkage program. The Developing Economies. 2010 Mar;48(1):156-76.

Hamza, H. (2013). Sharia governance in Islamic banks: effectiveness and supervision model. International Journal of Islamic and Middle Eastern Finance and Management. [emerald.com]

Hasan, R., Siraj, S. A., \& Mohamad, M. H. S. (2017). Antecedents and Outcome of Waqif's Trust in Waqf Institution. Journal of Economic Cooperation \& Development, 38(4), 155-179.
Hanefah, H. M. M., Jalil, A., Ramli, A. M., Sabri, H., Nawai, N., \& Shahwan, S. (2011). Financing The Development Of Waqf Property: The Experience Of Malaysian And Singapore.

Hughes, J. P. (2013). A new cost efficiency measure for not-for-profit firms: Evidence of a link between inefficiency and large endowments. Atlantic Economic Journal, 41(3), 279-300.

Kahf, M. (2003, January). The role of waqf in improving the ummah welfare. In International Seminar on Waqf as a Private Legal Body (pp. 67).

Kuran, T. (2001). The provision of public goods under Islamic law: Origins, impact, and limitations of the waqf system. Law and Society Review, 841898 .

Makki, M. A. (2010). Impact of corporate governance on intellectual capital efficiency and financial performance (Doctoral dissertation, National College of Business Administration \& Economics Lahore).

Marwah H, Bolz AK. (2009). Waqfs and trusts: a comparative study. Trusts \& Trustees. 2009 Dec 1;15(10):811-6.

Mensah, Y. M., Lam, K. \& Warner, R. (2008). An Approach To Evaluating Relative Effectiveness In Non-Profit Institutions. Journal of Public Budgeting, Accounting and Financial Management, 20(3), 324-354.

Ministry of Religion. Laporan Akuntabilitas Kinerja Instansi Pemerintah: Kementerian Agama Tahun 2013. Jakarta: Kementerian Agama. 2014.

Mohammad, M. T. T. H. (2009). Alternative development financing instruments for waqf properties. Malaysian Journal of Real Estate, 4(2), 45-59.

Mohsin, M. I. A. (2012). Waqf-shares: new product to finance old waqf properties. Banks \& bank systems, (7, Iss. 2), 72-78.

Mohsin, M. I. A. (2010). Revitalization of waqf administration \& family waqf law. US-China Law Review, 7, 57.

Musibah AS, Alfattani WS. (2014). The mediating effect of financial performance on the relationship between Shariah supervisory board effectiveness, intellectual capital and corporate social responsibility, of Islamic banks in Gulf Cooperation Council countries. Asian Social Science. 2014 Sep 1;10(17):139. 
Nathan S. (2010) The performance of Shari'ah supervisory boards within Islamic financial institutions in the Gulf Cooperation Council countries. Corporate Ownership \& Control. 2010;247.

Noordin, N. H., Haron, S. N., \& Kassim, S. (2017). Developing a comprehensive performance measurement system for waqf institutions. International Journal of Social Economics.

OECD (Organisation for Economic Co-operation and Development) (2004) Principles of Corporate Governance, France: OECD Publications.

Patra, S. (2009), Financial Performance of Iron and Steel Industry in India: An Analytical and Comparative Study of Some Selected Companies During 1995-1996 To 2004-2005 (Doctoral thesis).

Ramli, N. M., \& Muhamed, N. A. (2013, December). Good governance framework for corporate waqf: Towards accountability enhancement. In Paper accepted for Proceedings Of World Universities' Islamic Philanthropy Conference.

Rangkuti, F. (2010). Spiritual Leadership in Business, Jakarta: PT. Gramedia Pustaka Utama.

Rothbard, N. M. The Mystery of Banking (2 ed.). (2008). Auburn, Alabama: Ludwig von Mises Institute. 2008.

Shafii, Z., Yunanda, R. A., \& Rahman, F. K. (2014). Financial And Operational Measures Of Waqf Performance: The Case Of State Islamic Religion Council Of Singapore And Malaysia.

Sulaiman, M., \& Zakari, M. A. (2015). Efficiency and effectiveness of waqf institutions in Malaysia: toward financial sustainability. Access to finance and human development - essays on zakah, awqaf and microfinance, 43.

Wahab NA, Rahman AR. (2015). Efficiency of zakat institutions and its determinants. Access to Finance and Human Development-Essays on Zakah, Awqaf and Microfinance. 2015;33.

Zeller M, Meyer RL, editors (2002). The triangle of microfinance: Financial sustainability, outreach, and impact. Intl Food Policy Res Inst; 2002. 